\title{
PEMANFAATAN JAGUNG (Zea mays L) SEBAGAI BAHAN PEMBUATAN ES KRIM
}

\section{THE UTILIZATION OF CORN (Zea mays L.) AS MATERIALS FOR ICE CREAM}

\author{
Methatias Ayu Moulina \\ Program Studi Teknologi Pangan Fakultas Pertanian, Universitas Dehasen Bengkulu
}

\begin{abstract}
ABSTRAK
Es krim merupakan makanan dengan gizi tinggi. Salah satu bahan yang digunakan dalam pembuatan es krim adalah susu skim. Penelitian ini bertujuan untuk mengetahui pengaruh substitusi jagung terhadap sifat fisik, organoleptik, kadar substiusi yang yang paling disukai panelis dan sifat kimia es krim. Penelitian ini dilakukan untuk menguji tingkat kesukaan terhadap es krim yang paling disukai konsumen dengan substitusi jagung sebanyak 0\%, 25\%, $50 \%$ dan $75 \%$. Data sifat fisik yang diperoleh dianalisa dengn menggunakan analisa sidik ragam (ANOVA) pada taraf signifikan 5\%. Apabila terdapat perbedaan yang nyata maka akan diuji lanjut dengan menggunakan uji Tukey. Hasil analisa keragaman menunjukkan bahwa perlakuan berbeda nyata terhadap overrun dan kecepatan meleleh, dan perlakuan tidak berbeda nyata $(\mathrm{P}>0,05)$ terhadap warna, aroma dan rasa es krim, tetapi sangat berbeda nyata $(\mathrm{P}<0,01)$ terhadap mouthfeel dan penampilan secara umum. Hasil uji organoleptik menunjukkan bahwa es krim yang paling disukai konsumen adalah perlakuan substitusi jagung terhadap susu skim sebanyak 50\% : 50\% dengan kandungan kadar lemak sebesar 10,19\% dan kandungan kadar protein sebesar 4,73\%.
\end{abstract}

Kata kunci : Es krim, Jagung, susu skim.

\section{ABSTRACT}

Ice cream is food with high nutrient. One of ingredient that used in making of cream is skim milk. This research was aimed to know the corn substitution influence towards physical character, organoleptic, most liked consumer treatment levels corn substitution towards skim milk and chemistry character of ice cream. This research done by evaluated of ice cream towards consumers pleasure degree with corn substitution as much as 0\%, 25\%, 50\%, $75 \%$ and $100 \%$. Physical character data was analyzed of Variance (ANOVA) on significant level at 5\%. Different data analysed will be continued by Tukey test. The result showed that there were significant different on overrun and rapid melt and not significant different $(P>0,05)$ on colour, flavour and taste of ice cream, but very significant different $(P<0,01)$ on mouthfeel and general appearance. Result organoleptic test show that there were most liked consumer treatment corn substitution towards skim milk as much as 50\%:50\%, with amount fat as 10,19\% and protein as 4,73\%. In can be concluded that as well as corn used substitution skim milk on making ice cream is substitution ratio as much as $50 \%$ to be treatment most liked by panelist.

Keywords: ice cream, corn, skim milk 


\section{PENDAHULUAN}

Es krim merupakan makanan dengan gizi tinggi. Es krim sudah dikenal sejak zaman Romawi atau 400 tahun SM, ternyata mampu menyembuhkan influenza, serta mengandung zat anti tumor. Pada tahun 1851 es krim dapat dikatakan jenis hidangan paling populer di dunia (Anonim ${ }^{\mathrm{a}}$, 2008).

Susu skim dapat digunakan sebagai bahan baku pembuatan makanan dengan tujuan untuk mendapatkan nilai kalori yang rendah yang terkandung dalam makanan tersebut, karena susu skim hanya mengandung 55\% dari seluruh energi susu sehingga susu skim sangat baik digunakan dalam pembuatan keju dengan lemak rendah dan yoghurt serta es krim (Buckle, 1987). Susu skim atau semi skim yang diproduksi memiliki kandungan lemak antara $\quad 1 \%$ sampai $2 \%$ sehingga memberikan pilihan yang lebih bervariasi pada konsumen (Smith, 2009). Akan tetapi dipasaran harga susu skim relatif sangat mahal sehingga dibutuhkan alternatif bahan pensubstitusi atau pengganti.

Jagung (Zea mays L) merupakan salah satu tanaman pangan dunia yang terpenting, selain gandum dan padi. Penduduk beberapa daerah di Indonesia seperti di Madura dan Nusa Tenggara menggunakan jagung sebagai pangan pokok. Biji jagung kaya akan karbohidrat.
Kandungan karbohidrat dapat mencapai $80 \%$ dari seluruh bahan kering biji. (Anonim $\left.{ }^{\mathrm{c}}, 2008\right)$.

Oleh karena itu melihat komposisi kimia yang terkandung dalam jagung yang memiliki lemak relatif rendah (4\%) dan memiliki protein sekitar 10\% serta melihat potensi produksi yang dimiliki Provinsi Bengkulu, maka penelitian ini akan menggunakan jagung sebagai campuran bahan baku pembuatan es krim sebagai bahan pensubstitusi susu skim yang digunakan sebagai sumber BKTL pada es krim.

\section{METODE PENELITIAN}

\section{Alat dan Bahan}

Alat-alat yang digunakan adalah baloon wisk, neraca analitik merk Ohaus, kompor gas, blender merk Philips, mixer merk Philips, alat pengukus, wadah adonan dan alat pengaduk, thermometer, wadah es krim, lemari pendingin (dengan refrigerator dan freezer), ice cream maker merk JMI kapasitas 1 liter, gelas ukur, labu ukur, pipet tetes, soxhlet, kertas saring, oven, labu kjedahl, erlenmeyer 250 $\mathrm{ml}$ dan $650 \mathrm{ml}$.

Bahan-bahan yang digunakan dalam penelitian ini adalah Susu bubuk full cream merk Dancow, susu skim bubuk, jagung (Zea mays L), gula pasir, kuning telur, agar-agar dan air dengan komposisi pada Tabel 1. 
Tabel. 1. Komposisi bahan baku es krim

\begin{tabular}{llccccc}
\hline \multirow{2}{*}{ No } & Bahan baku & \multicolumn{5}{c}{ Komposisi } \\
\cline { 2 - 6 } & & P0 & P1 & P2 & P3 & P4 \\
\hline 1. & Susu full cream & 140 & 140 & 140 & 140 & 140 \\
2 & Susu skim (g) & 100 & 75 & 50 & 25 & 0 \\
3. & Jagung (g) & 0 & 25 & 50 & 75 & 100 \\
4. & Gula pasir (g) & 200 & 200 & 200 & 200 & 200 \\
5. & Kuning telur (btr)) & 1 & 1 & 1 & 1 & 1 \\
6. & Agar- agar (g) & 2 & 2 & 2 & 2 & 2 \\
7 & Air (ml) & 1000 & 1000 & 1000 & 1000 & 1000 \\
\hline
\end{tabular}

Sumber : Padaga dan Manik, (2005)

Sedangkan bahan- bahan kimia meliputi dietil ether, larutan $\mathrm{K}_{2} \mathrm{SO}_{4}$, Larutan $\mathrm{CUSO}_{4}$, larutan $\mathrm{H}_{2} \mathrm{SO}_{4}$, larutan $\mathrm{NaOH}$ $50 \%$, larutan HCL $0,1 \mathrm{~N}$.

\section{Rancangan Penelitian}

Perlakuan yang digunakan dalam penelitian adalah perbandingan penggunaan susu skim dan jagung sebagai BKTL. Formulasi bahan yang digunakan dalam pembuatan es krim jagung ini mengacu pada Padaga dan Manik, (2005). Rancangan yang digunakan dalam penelitian ini adalah nonparametrik kruskal wallis test dengan satu faktor beda yaitu persentase substitusi padatan bukan lemak dengan 25 orang panelis sebagai ulangannya. Adapun perlakuan yang digunakan sebagai berikut :

$\mathrm{P} 0=$ Susu skim $:$ jagung $=100 \%: 0 \%$

$\mathrm{P} 1=$ Susu skim $:$ jagung $=75 \%: 25 \%$
$\mathrm{P} 2=$ Susu skim $:$ jagung $=50 \%: 50 \%$

$\mathrm{P} 3=$ Susu skim $:$ jagung $=25 \%: 75 \%$

$\mathrm{P} 4=$ Susu skim $:$ jagung $=0 \%: 100 \%$

\section{Variabel Pengamatan}

Dalam penelitian ini variabel pengamatan yang diteliti yaitu :

1. Analisa fisik (overrun dan kecepatan meleleh)

2. Uji organoleptik

3. Analisa kimia (kadar lemak dan kadar protein)

\section{Tahapan Penelitian}

\section{Pembuatan Es Krim}

Proses dasar dalam pembuatan es krim meliputi beberapa tahap, yaitu pencampuran bahan, pasteurisasi, homogenisasi, pematangan (aging), pembekuan dan agitasi, pengemasan, pembekuan, dan penyimpanan (Padaga 
dan Manik, 2005). Proses pembuatan es krim yang dilakukan dalam penelitian adalah sebagai berikut :

(1)Biji jagung dicuci, dikukus

(2)Dihaluskan

(3)Kuning telur dikocok sampai mengembang

(4)Bahan-bahan kering sesuai perlakuan $\left(\mathrm{P}_{0}, \mathrm{P}_{1}, \mathrm{P}_{2}, \mathrm{P}_{3}, \mathrm{P}_{4}\right)$ dimasukkan ke dalam air hangat sambil diaduk

(5)Campuran dipanaskan, sambil kuning telur, dan agar-agar dimasukkan dan terus diaduk

(6)Dipasteurisasi pada suhu $80-85^{\circ} \mathrm{C}$ selama 25 detik

(7)Adonan diangkat, didinginkan sampai suam-suam kuku, kemudian dihomogenisasi selama 15 menit

(8)Adonan disimpan di dalam refrigerator pada suhu $4^{\circ} \mathrm{C}$ selama minimal 4 jam untuk proses aging

(9)Dihomogenisasi ulang selama 15 menit (10) Adonan disimpan di dalam freezer sampai setengah beku pada suhu $-5^{\circ} \mathrm{C}$ sampai $-8^{\circ} \mathrm{C}$ lalu diagitasi selama 30 menit

(11) Dikemas dalam wadah-wadah kemudian disimpan kembali ke dalam freezer pada suhu $-25^{\circ} \mathrm{C}$ sampai $-30^{\circ} \mathrm{C}$.

(12) Dilakukan penguian sifat fisik (over run kecepatan meleleh/mencair), sifat kimia (lemak, protein) dan uji hedonik.

\section{Analisa Data}

Data hasil pengujian sifat fisik dianalisa dengan analisa varian taraf signifikan 5\%, sedangkan data hasil uji organoleptik akan dianalisa dengan statistik untuk data non parametrik uji Kruskal Wallis pada taraf signifikan 5\% (Nugroho ${ }^{\mathrm{a}}$, 2008). Jika terdapat perbedaan yang nyata maka akan dilakukan uji lanjut dengan menggunakan Uji Tukey pada taraf signifikan 5\% (Nugroho ${ }^{\mathrm{b}}$, 2008; Zar, 1984)

\section{HASIL DAN PEMBAHASAN}

\section{Pengujian Mutu Fisik Es Krim}

\section{Overrun}

Data hasil perhitungan nilai rataan overrun dapat dilihat pada Gambar. 1.

Berdasarkan data overrun tersebut maka $\mathrm{P}_{0}$ memiliki penambahan volume yang memenuhi standar pengembangan volume untuk es krim yang berkualitas sedangkan $\mathrm{P}_{3}$ dan $\mathrm{P}_{4}$ tergolong pada overrun untuk es krim produksi rumah tangga. $\mathrm{P}_{1}$ dan $\mathrm{P}_{2}$ digolongkan pada industri kecil dan menengah.

Dari data overrun dapat disimpulkan bahwa semakin tinggi konsentrasi substitusi jagung yang ditambahkan maka semakin rendah nilai overrun yang dihasilkan. Hal tersebut diduga disebabkan oleh kandungan bahan kering tanpa lemak yang berasal dari jagung, dimana bahan tersebut menyebabkan 
kekentalan (viscositas) dari adonan es krim semakin tinggi.

Hasil analisa keragaman terhadap overrun menunjukkan bahwa antar perlakuan berbeda nyata $(\mathrm{P}<0,05)$. Hasil uji lanjut terhadap overrun es krim dapat dilihat pada Tabel. 3.

\section{Kecepatan Meleleh}

Setianawati (2002) menyatakan bahwa daya pelelehan identik dengan waktu yang dibutuhkan untuk meleleh sempurna pada suhu ruang. Es krim yang berkualitas baik adalah yang resisten terhadap pelelehan. Data kecepatan meleleh pada es krim jagung disajikan pada Gambar. 2.

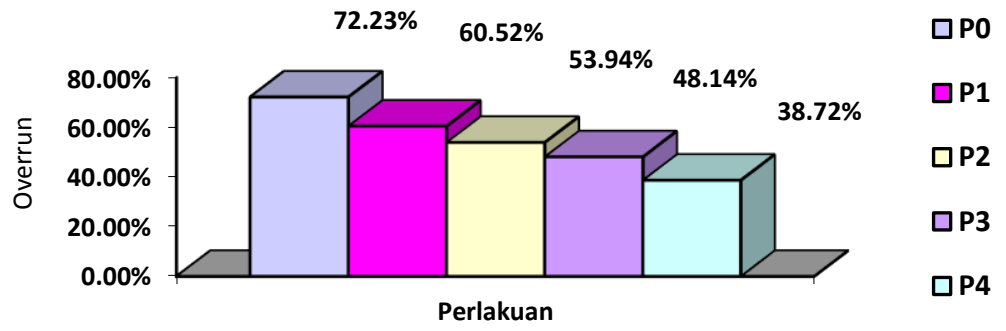

Gambar. 1. Overrun es krim jagung

Tabel. 3. Hasil uji lanjut Tukey terhadap overrun es krim

\begin{tabular}{cccccc}
\hline comparison & selisih & SE & $\mathbf{Q}$ & q tabel & conclusion \\
\hline P0 vs P1 & 0,1172 & 0,053037 & 2,208849 & 5,673 & Tn \\
P0 vs P2 & 0,1830 & 0,053037 & 3,4495 & 5,673 & Tn \\
P0 vs P3 & 0,2410 & 0,053037 & 4,543083 & 5,673 & Tn \\
P0 vs P4 & 0,3352 & 0,053037 & 6,319213 & 5,673 & $*$ \\
P1 vs P2 & 0,0658 & 0,053037 & 1,240643 & 5,673 & tn \\
P1 vs P3 & 0,1238 & 0,053037 & 2,33422 & 5,673 & tn \\
P1 vs P4 & 0,2180 & 0,053037 & 4,110338 & 5,673 & tn \\
P2 vs P3 & 0,0580 & 0,053037 & 1,093576 & 5,673 & tn \\
P2 vs P4 & 0,1522 & 0,053037 & 2,869695 & 5,673 & tn \\
P3 vs P4 & 0,0942 & 0,053037 & 1,776119 & 5,673 & tn
\end{tabular}

Ket : * pada baris yang sama menunjukkan berbeda nyata 


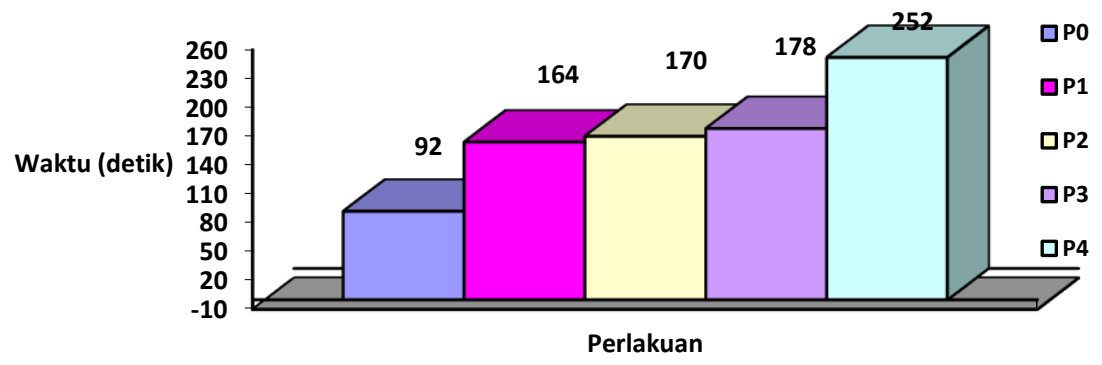

Gambar. 2. Kecepatan meleleh es krim jagung

Tabel. 4. Hasil uji lanjut Tukey terhadap kecepatan meleleh es krim

\begin{tabular}{cccccc}
\hline comparison & Selisih & SE & Q & q tabel & Conclusion \\
\hline P1 vs P0 & 72,2 & 16,57 & 4,36 & 4,232 & $*$ \\
P2 vs P0 & 78 & 16,57 & 4,71 & 4,232 & $*$ \\
P2 vs P1 & 5,8 & 16,57 & 0,35 & 4,232 & TN \\
P3 vs P0 & 85,8 & 16,57 & 5,18 & 4,232 & $*$ \\
P3 vs P1 & 13,6 & 16,57 & 0,82 & 4,232 & TN \\
P3 vs P2 & 7,8 & 16,57 & 0,47 & 4,232 & TN \\
P4 vs P0 & 160 & 16,57 & 9,66 & 4,232 & $*$ \\
P4 vs P1 & 87,8 & 16,57 & 5,30 & 4,232 & $*$ \\
P4 vs P2 & 82 & 16,57 & 4,95 & 4,232 & $*$ \\
P4 vs P3 & 74,2 & 16,57 & 4,48 & 4,232 & $*$ \\
\hline
\end{tabular}

Ket : * pada baris yang sama menunjukkan berbeda nyata

Berdasarkan data tersebut dapat diketahui bahwa semakin tinggi substitusi jagung ke dalam adonan es krim maka semakin lama waktu yang dibutuhkan oleh es krim untuk dapat meleleh di suhu ruang. Penurunan kecepatan meleleh diduga terjadi karena peningkatan kekentalan ICM akibat kandungan amilum yang terkandung dalam jagung.
Pengujian Sifat Organoleptik Es Krim

\section{Hasil Uji Organoleptik Terhadap}

\section{Sampel Es Krim}

Uji kesukaan (uji hedonik) merupakan pengujian untuk mengetahui tentang tanggapan secara pribadi panelis tentang kesukaan atau ketidaksukaan terhadap suatu produk yang diuji, yang biasa dikemukakan dalam bentuk tingkattingkat kesukaan atau skala hedonik (Soekarto, 1985). 
Hasil analisa keragaman dengan menyerupai warna dari bahan baku susu menggunakan uji kruskal-wallis menunjukkan bahwa untuk variabel mouthfeel dan penampilan secara umum perlakuan sangat berbeda nyata $(\mathrm{P}<0,01)$, akan tetapi untuk variabel warna, aroma dan rasa perlakuan tidak berbeda nyata $(\mathrm{P}>0,05)$.

\section{Pengaruh Perlakuan Terhadap Warna}

\section{Es Krim}

Rataan hasil perankingan dari penilaian panelis untuk tiap-tiap perlakuan disajikan pada Gambar. 3. Berdasarkan data yang disajikan pada Gambar. 3. diatas, secara umum warna es krim yang dihasilkan yang digunakan yaitu cenderung putih kekuning-kuningan. Timbulnya warna ini diduga karena komposisi susu full cream sebagai bahan utama dari pembuatan es krim yang lebih dominan dalam memberi warna es krim. Berdasarkan data yang disajikan pada Gambar. 3, secara umum warna es krim yang dihasilkan menyerupai warna dari bahan baku susu yang digunakan yaitu cenderung putih kekuning-kuningan. Timbulnya warna ini diduga karena komposisi susu full cream sebagai bahan utama dari pembuatan es krim yang lebih dominan dalam memberi warna es krim.

Tabel. 5. Rekapitulasi data rataan skor hasil pengujian organoleptik terhadap sampel es krim

\begin{tabular}{lcccccc}
\hline \multirow{2}{*}{\multicolumn{1}{c}{ Sifat organoleptik }} & \multicolumn{5}{c}{ Perlakuan } & \multirow{2}{*}{ Probabilitas } \\
\cline { 2 - 6 } & P0 & P1 & P2 & P3 & P4 & \\
\hline Warna & 3,88 & 3,56 & 3,92 & 3,92 & 4,00 & ns \\
Aroma & 3,64 & 3,56 & 3,84 & 3,60 & 3,68 & ns \\
Rasa & 3,88 & 3,68 & 4,00 & 3,72 & 3,72 & ns \\
Mouthfeel & 3,48 & 3,52 & 4,04 & 3,96 & 3,28 & $* *$ \\
Penampilan secara umum & 3,72 & 3,72 & 4,24 & 3,76 & 3,64 & $* *$ \\
\hline
\end{tabular}

Ket. ns pada baris yang sama menunjukkan perbedaan yang tidak nyata $(\mathrm{P}>0,05)$ ** pada baris yang sama menunjukkan sangat berbeda nyata $(\mathrm{P}<0,01)$ 


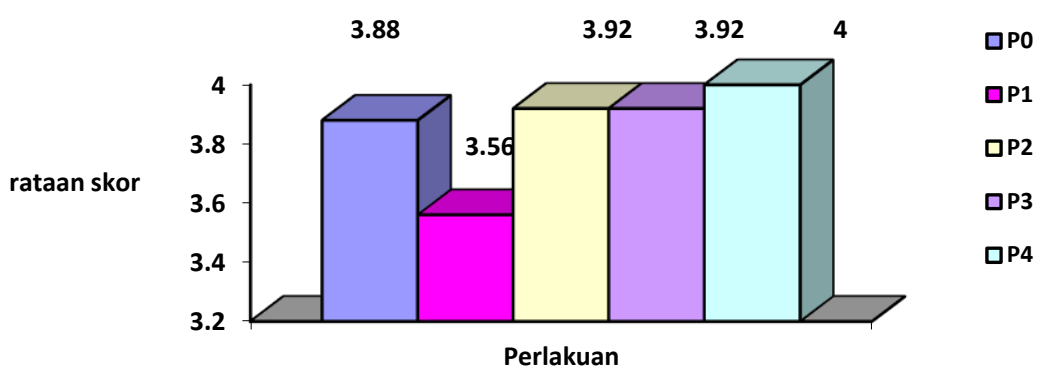

Gambar. 3. Rataan hasil ranking uji organoleptik terhadap warna es krim

\section{Pengaruh Perlakuan Terhadap Aroma}

\section{Es Krim}

\section{Pengaruh Perlakuan Terhadap Rasa Es}

Berdasarkan data pada Gambar. 4, Rata-

\section{Krim}

rata panelis menilai bahwa aroma yang

Berdasarkan data pada Gambar. 5, hasil dihasilkan dari es krim tersebut masih mencirikan bahan utama (susu). Selain itu diduga karena adanya penambahan bahan uji organoleptik terhadap rasa es krim menunjukkan bahwa $\mathrm{P}_{2}$ memiliki rataan skor tertinggi yaitu sebesar 4,00 penstabil dalam ICM. Penambahan bahan sedangkan perlakuan yang memiliki penstabil menyebabkan terperangkapnya aroma (susu) di dalam adonan terutama bila adonan mempunyai kekentalan yang tinggi (Mutiara, 2000 disitasi Setianawati, 2002).

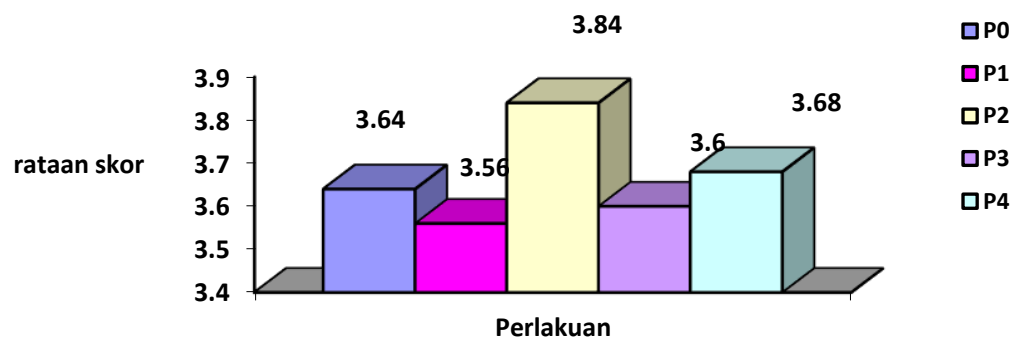

Gambar. 4. Rataan hasil ranking uji organoleptik terhadap aroma es krim 


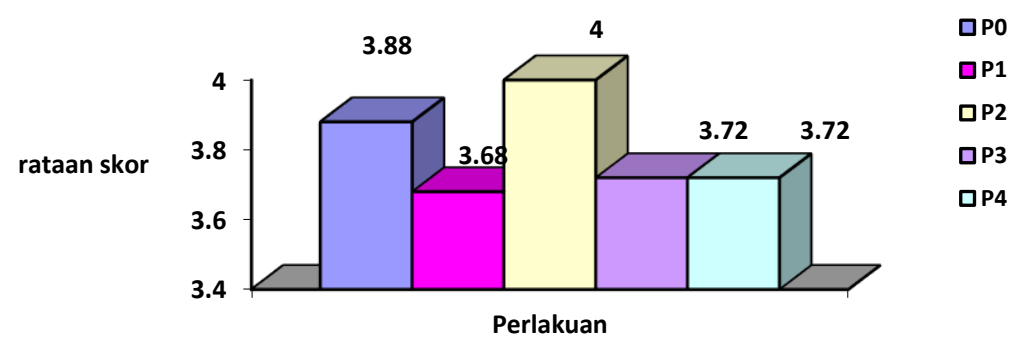

Gambar. 5. Rataan hasil ranking uji organoleptik terhadap rasa es krim

Dari hasil analisa keragaman KruskalWallis test terhadap aroma es krim menunjukkan tidak berbeda nyata antar perlakuan $(\mathrm{P}>0,05)$. Hal ini ditunjukkan pada produk es krim tersebut, rasa yang dominan adalah rasa manis yang timbul akibat susu full cream dan penambahan gula. Menurut Padaga dan Manik (2005), penambahan pengental dapat mengurangi rasa manis gula dan perubahan tekstur dapat mengubah cita rasa es krim. Akan tetapi meskipun penambahan komposisi jagung pada tiap-tiap perlakuan sebagai sumber BKTL meningkatkan kekentalan (viscositas) es krim, rasa manis gula dan susu masih dapat bertahan dalam es krim sebagai rasa yang dominan. Rasa manis tersebut bertahan diduga karena terdapatnya laktosa yang berasal dari jagung. Hal ini sesuai dengan laporan Astawan (2008) yang menyatakan bahwa salah satu komponen dari golongan karbohidrat yang telah diteliti fungsinya adalah laktosa. Laktosa akan menambah cita rasa dan mempertahankan palatabilitas (rasa enak) es krim.

\section{Pengaruh Perlakuan Terhadap Mouthfeel Es Krim}

Menurut Padaga dan Manik (2005), tekstur es krim yang baik adalah tidak keras, lembut (smooth), dan tampak mengkilat.

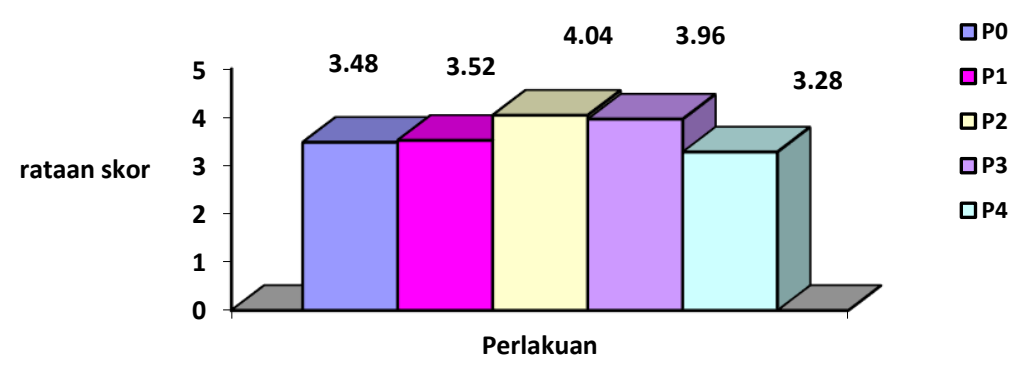

Gambar. 6. Rataan hasil ranking uji organoleptik terhadap mouthfeel es krim 
Berdasarkan data pada Gambar. 6. rataan skor pada hasil uji organoleptik terhadap mouthfeel es krim menunjukkan $\mathrm{P}_{2}$ memiliki rataan skor tertinggi yaitu sebesar 4,04 sedangkan perlakuan yang memiliki skor terendah yaitu $\mathrm{P}_{4}$ dengan rataan skor penilaian yaitu sebesar 3,28. Dari hasil analisa keragaman KruskalWallis test terhadap mouthfeel es krim menunjukkan bahwa H0 ditolak (tidak diterima) dimana $\mathrm{H}_{\text {hitung }}$ yaitu sebesar 19,017 lebih besar dari $\mathrm{H}_{\text {tabel }}$ yaitu sebesar 9,488 $\left(\mathrm{H}_{\text {hitung }}>\mathrm{H}_{\text {tabel }}\right)$. Hasil analisa keragaman juga menunjukkan sangat berbeda nyata antar perlakuan $(\mathrm{P}<0,01)$. Hal ini diduga karena adanya keseimbangan komposisi nutrisi jagung dengan susu skim yang digunakan dimana terdapat keseimbangan rasio protein (jagung $\pm 4 \%$; susu skim 3,5\%) dan lemak (jagung $\pm 1,3 \%$; susu skim 0,5 2\%). Hal ini sesuai dengan pendapat Purnomo (1995), yang menyatakan bahwa banyak hal yang mempengaruhi tekstur bahan pangan antara lain rasio kandungan protein, lemak, jenis protein, suhu pengolahan, kadar air dan aktivitas air.

Tabel. 6. Hasil uji lanjut Tukey terhadap mouthfeel es krim

\begin{tabular}{cccccc}
\hline Comparison & selisih & SE & q & q tabel & Conclusion \\
\hline P0 vs P4 & 240 & 181,14 & 1,32 & 3,858 & tn \\
P1 vs P0 & 20,5 & 181,14 & 0,11 & 3,858 & tn \\
P1 vs P4 & 260,5 & 181,14 & 1,44 & 3,858 & tn \\
P2 vs P0 & 576 & 181,14 & 3,18 & 3,858 & tn \\
P2 vs P1 & 555,5 & 181,14 & 3,07 & 3,858 & tn \\
P2 vs P3 & 70 & 181,14 & 0,39 & 3,858 & tn \\
P2 vs P4 & 816 & 181,14 & 4,50 & 3,858 & $*$ \\
P3 vs P0 & 506 & 181,14 & 2,79 & 3,858 & tn \\
P3 vs P1 & 485,5 & 181,14 & 2,68 & 3,858 & tn \\
P3 vs P4 & 746 & 181,14 & 4,12 & 3,858 & $*$ \\
\hline Ket : pada bar & yang & & & \\
\hline
\end{tabular}

Ket : * pada baris yang sama menunjukkan berbeda nyata 


\section{Pengaruh Perlakuan Terhadap} Penampilan Secara Umum Es Krim

Uji organoleptik untuk penampilan secara umum dilakukan dengan menilai secara umum atau keseluruhan parameter dengan menggunakan gabungan parameter warna, aroma, rasa dan mouthfeel es krim yang bertujuan untuk memilih perlakuan yang paling disukai panelis.

Berdasarkan data pada Gambar. 7. rataan skor hasil uji organoleptik terhadap penampilan secara umum es krim menunjukkan bahwa perlakuan yang memiliki rataan skor penilaian tertinggi adalah $\mathrm{P}_{2}$, hal ini diduga karena $\mathrm{P}_{2}$ memiliki warna yang menarik (warna lembut) yaitu wana putih kekuningan, aroma susu yang tidak terlalu kuat (tidak amis), rasa yang enak serta mouthfeel yang lembut di lidah.

Dari hasil analisa keragaman Kruskal-Wallis test terhadap penampilan secara umum es krim menunjukkan bahwa H0 ditolak (tidak diterima) dimana $\mathrm{H}_{\text {hitung }}$ yaitu sebesar 15,128 lebih besar dari $\mathrm{H}_{\text {tabel }}$ yaitu sebesar 9,488 $\left(\mathrm{H}_{\text {hitung }}>\right.$ $\left.\mathrm{H}_{\text {tabel}}\right)$. Hasil analisa keragaman juga menunjukkan sangat berbeda nyata antar perlakuan $(\mathrm{P}<0,01)$.

Hasil uji lanjut dengan metode Tukey pada Tabel. 7. menunjukkan bahwa perlakuan $\mathrm{P}_{2}$ berbeda nyata (nilai $\mathrm{q}>$ nilai $\mathrm{q}$ tabel) dengan $\mathrm{P}_{4}$, namun tidak berbeda nyata dengan $\mathrm{P}_{0}, \mathrm{P}_{1}$ dan $\mathrm{P}_{3}$. Sementara perlakuan $\mathrm{P}_{0}, \mathrm{P}_{1}, \mathrm{P}_{3}$ dan $\mathrm{P}_{4}$ tidak berbeda nyata satu dengan yang lainnya.

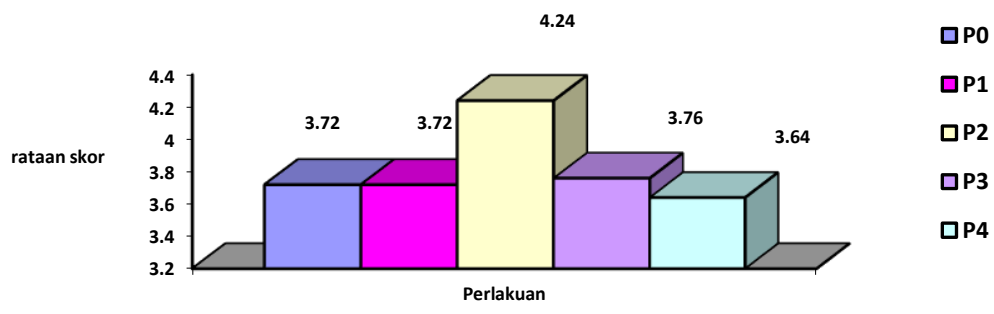

Gambar. 7. Rataan hasil ranking uji organoleptik terhadap penampilan secara umum es krim 
Tabel. 7. Hasil uji lanjut Tukey terhadap penampilan secara umum es krim

\begin{tabular}{cccccc}
\hline Comparison & Selisih & SE & q & q tabel & Conclusion \\
\hline P0 vs P1 & 71,5 & 181,14 & 0,39 & 3,858 & TN \\
P0 vs P4 & 140,5 & 181,14 & 0,78 & 3,858 & TN \\
P1 vs P4 & 69 & 181,14 & 0,38 & 3,858 & TN \\
P2 vs P0 & 598 & 181,14 & 3,30 & 3,858 & TN \\
P2 vs P1 & 669,5 & 181,14 & 3,70 & 3,858 & TN \\
P2 vs P3 & 544 & 181,14 & 3,00 & 3,858 & TN \\
P2 vs P4 & 738,5 & 181,14 & 4,08 & 3,858 & $*$ \\
P3 vs P0 & 54 & 181,14 & 0,30 & 3,858 & TN \\
P3 vs P1 & 125,5 & 181,14 & 0,69 & 3,858 & TN \\
P3 vs P4 & 194,5 & 181,14 & 1,07 & 3,858 & TN \\
\hline
\end{tabular}

Ket : * pada baris yang sama menunjukkan berbeda nyata

\section{Pengujian Mutu Kimia Es Krim}

\section{Pengaruh Perlakuan Terhadap Kadar}

lemak

Pada pengujian kandungan kimia dilakukan terhadap perlakuan yang memiliki tingkat kesukaan paling tinggi, melalui analisa proksimat kandungan lemak diperoleh kadar lemak es krim dengan substitusi $50 \%$ jagung $\left(\mathrm{P}_{2}\right)$ yaitu sebesar 10,19 gram per 100 gram es krim. Buckle et al. (1985) menyatakan bahwa lemak pada komposisi rata-rata es krim adalah sebesar 11,5\%. Hasil uji lemak pada penelitian ini masih lebih rendah dari komposisi lemak es krim pada umumnya. Hal ini diduga karena substitusi jagung pada $\mathrm{P}_{2}$ menurunkan kandungan lemak es krim dimana jagung yang digunakan memiliki kandungan lemak yang relatif rendah yaitu berkisar 1,3-4\%.

Di dalam SII Nomor 1.617 tahun 1985 menyebutkan ketentuan mengenai besarnya kandungan lemak di dalam es krim dengan standar minimal 8,0\%. Hal ini menunjukkan bahwa lemak es krim pada $\mathrm{P}_{2}$ masih memenuhi standar SII, sedangkan Padaga dan Manik (2005) mengkategorikan es krim dengan kadar lemak 10-12\% dalam kategori standar. Kandungan lemak pada $\mathrm{P}_{2}$ diduga memberikan tampilan yang baik secara fisik pada nilai overrun dan kecepatan meleleh. 


\section{Pengaruh Perlakuan Terhadap Kadar}

Protein

\section{Pengujian kandungan kimia dilakukan terhadap perlakuan yang} memiliki tingkat kesukaan paling tinggi. Melalui analisa proksimat kandungan protein dengan metode kjedhal diperoleh kadar protein es krim dengan substitusi $50 \%$ jagung $\left(\mathrm{P}_{2}\right)$ sebesar 4,73 gram per 100 gram bahan. Buckle et al. (1985) menyatakan bahwa protein pada komposisi rata-rata es krim adalah sebesar 4,6 \%. Hasil uji protein pada penelitian ini memenuhi standar komposisi protein es krim pada umumnya.

Di dalam SII Nomor 1.617 tahun 1985 tidak menyebutkan ketentuan mengenai besarnya kandungan protein di dalam es krim, namun jika dibandingkan dengan kadar protein es krim walls sebesar 1,3 gram, maka kandungan protein dari es krim jagung pada penelitian ini masih lebih tinggi yaitu sebesar 4,73 gram. Tingginya komposisi protein pada es krim penelitian ini diduga karena adanya supply protein dari jagung yang digunakan sebagai bahan pensubstitusi susu skim sebesar 50\% $\left(\mathrm{P}_{2}\right)$ dimana protein jagung berkisar 4-10\% sedangkan protein susu skim $\pm 3,5 \%$.

\section{KESIMPULAN}

Hasil uji mutu fisik terhadap overrun dan kecepatan meleleh diperoleh bahwa semakin tinggi konsentrasi substitusi jagung yang ditambahkan maka semakin rendah nilai overrun dan semakin tinggi nilai kecepatan meleleh. Berdasarkan hasil uji organoleptik diperoleh bahwa penggunaan jagung sebagai bahan pensubstitusi susu skim dalam pembuatan es krim memberikan pengaruh nyata terhadap mouthfeel dan penampilan secara umum es krim, namun tidak berpengaruh nyata terhadap warna, aroma dan rasa es krim. Penggunaan jagung sebagai bahan pensubstitusi susu skim dalam pembuatan es krim dengan kadar substitusi sebanyak 50\% $\quad\left(\mathrm{P}_{2}\right)$ merupakan perlakuan yang paling disukai oleh panelis. Hasil uji mutu kimia terhadap perlakuan yang paling disukai oleh panelis diperoleh bahwa $\mathrm{P}_{2}$ memiliki kadar lemak 10,19 gram dan protein 4,73 gram.

\section{DAFTAR PUSTAKA}

Anonima'. 2008. Gizi dan Nutrisi "Sehat dengan es krim" ? http://www.jawaban.com/ news/health/detail.php?id_news $=0$ 70802155416\&off $\mathrm{x}=5$.

Anonim $^{\mathrm{b}}$. $2008 . \quad$ Jagung. http://id.wikipedia.org/wiki/Jagung Astawan, M. 2008. Ada penjinak virus di dalam es krim !. Pusat Data dan Informasi Depatemenkesehatan. http://www.depkes.go.id/index.php 
?option $=$ articles $\&$ task $=$ viewarticle \&artid=226\&Itemid=

Buckle, K.A., R.A. Edwards, G.H. Fleet, and M.Wooton. 1987. Food Science. Australian Vice Chancellors' committee. Diterjemahkan oleh Purnomo, H. dan Adiono. 1985. Ilmu Pangan. Universitas Indonesia. Jakarta

Kartika, B., Adi D.K., Didik P., dan Dyah I. 1992. Petunjuk evaluasi produksi industri hasil pertanian. UGM. Yogyakarta

Komalasari, L.F. 2005. Proses tradisional produksi yogurt dengan penambahan bahan baku tepung susu full cream dan tepung susu skim. Program Studi Teknologi Industri Pertanian. Fakultas Pertanian. Universitas Bengkulu (tidak dipublikasi)

Nugroho, $S^{\text {a }}$. 2008. Statistik non parametrik. Unib Press. Bengkulu

Nugroho, $S^{\text {b }}$. 2008. Dasar-dasar rancangan percobaan. Unib Press. Bengkulu

Padaga, M dan Manik E.S. 2005. Membuat es krim yang sehat. Trubus Agrisarana. Surabaya

Saleh, E. 2004. Teknologi pengolahan susu dan hasil ikutan ternak. Skripsi. Program Studi Produksi Ternak. Fakultas Pertanian.
Universitas Sumatera Utara (tidak dipublikasi)

Setianawati, Hijrah.N., Budi S.,dan Lilik N.Y. 2002. Penggunaan kombinasi bahan penstabil dalam pembuatan velva kweni (Mangifera odorata Griff.) dan Perubahan Mutu Selama Penyimpanan. Media Gizi dan Keluarga, Desember 2002, 26 (2) : 124-137

Soekarto, S.T. 1985. Penilaian organoleptik untuk industri pangan dan hasil pertanian. Bhatara Karya Aksara. Yogyakarta

Smith,S.E. 2009. What is Skim Milk?. conjecture corporation. http://www.wiseGEEK.com/ What-is-Skim-Milk/?

Syarief, R. dan Anies I. 1988. Pengetahuan bahan pangan untuk industri pertanian. PT. Mediyatama Sarana Perkasa. Jakarta

Wibowo, T. 1992. Pengaruh jenis dan konsentrasi bahan penstabil terhadap mutu velva fruit jambu biji. IPB. Bogor.

Zar, J. H. 1984. Biostatistical analysis. Second edition. Departemen of Biologycal Sciences. Northern Illonois University. Prentice-Hall International, Inc. USA. 